\title{
Comparative Study of Underlay Tympanoplasty with Temporalis Fascia and Tragal Perichondrium
}

\author{
${ }^{1}$ Rakesh Kumar, ${ }^{2}$ Rajesh Kumar suman, ${ }^{3}$ Yogesh A. Garje, ${ }^{4}$ Suman P. Rao, \\ ${ }^{I}$ Resident, Department of ENT, MGM Institute of Health sciences \\ ${ }^{2}$ Tutor, Department of pharmacology MGM Institute of Health sciences \\ ${ }^{3}$ Resident, Department of pharmacology MGM Institute of Health sciences \\ ${ }^{4}$ Prof and Head, Department of ENT, MGM Institute of Health sciences
}

\begin{abstract}
:
Background: Hearing is a sense that enables man to establish contact with his fellows via speech to experience life more fully. Deafness in varying degrees of severity is a big impediment to the integration of a person into the social structure. The otologist in the past had not much to offer to hearing handicapped people with chronic middle ear disease. With recent times the advent of the antibiotic era, the operating microscope and modern anesthetics techniques aimed at producing a dry, magnified operating field, have radically altered the outlook.

Methods: This study comprises of patients who were subjected to tympanoplasty for the treatment of chronic suppurative otits media. Each patient was subjected to a detail examination of nose, paranasal sinuses and throat to rule out any focus of infection, which could influence the result of tympanoplasty. 20 Patients were subjected to tympanoplasty with temporalis fascia while the remaining 20 patients underwent with tragal perichondrium Tympanoplasty is performed using temporalis fascia in 20 patients and tragal perichondrium in 20 patients in the age group of 15-45 years (males and females both). Patients with the complaint of discharging ear and decreased hearing were also screened .

Results: Majority of the patients shows mild to moderate hearing loss. $47.5 \%$ of them had air-one gap up to 20 $d B .52 .5 \%$ of them had air-bone gap 21-40 dB. None of them had air-bone gap above $40 \mathrm{~dB}$. In the postoperative hearing analysis, $77.5 \%$ of the patients showed air- bone gap upto $20 \mathrm{~dB}$. $22.5 \%$ of the patients showed air-bone gap in the range of $21-40 \mathrm{~dB} .80 \%$ of the patients operated with temporalis fascia showed air bone gap upto $20 \mathrm{~dB}$. $75 \%$ of the patients operated with tragal perichondrium showed air-bone gap upto $20 \mathrm{~dB}$. Mean improvement in hearing temporalis fascia is $09.5 \mathrm{~dB}$. Mean improvement in hearing using tragal perichondrium is $09.0 \mathrm{~dB}$. Mean improvement in hearing using tragal perichondrium is $09.0 \mathrm{~dB}$

Cnclusion: Tympanoplasty is the most effective method for control of the tubotympanic type of CSOM disease and hearing improvement. Both temporalis fascia and tragal perichondrium are excellent graft materials for closure of perforation of tympanic membrane and hearing improvement. Improvement in hearing is not significantly influenced by duration of disease, age or sex of patients.
\end{abstract}

Kew Words: Tympanoplasty, Tragal Perichondrium, Temporalis Fascia, hearing

\section{Introduction}

Hearing is a sense that enables man to establish contact with his fellows via speech to experience life more fully. Deafness in varying degrees of severity is a big impediment to the integration of a person into the social structure.

The otologist in the past had not much to offer to hearing handicapped people with chronic middle ear disease. With recent times the advent of the antibiotic era, the operating microscope and modern anesthetics techniques aimed at producing a dry, magnified operating field, have radically altered the outlook.

Permanent perforation of the tympanic membrane resulting as sequelae of chronic suppurative otitis media is a major cause of deafness. Stalwarts from past as far back as Hippocrates have asserted the same. Controversies range about every step of the operation from the incision to the material used for packing. A great deal of experimental work is being done often with contradictory results.

The first known attempt to close a perforation of tympanic membrane to improve hearing was made by Marcus Banzer in 1640 using prosthesis made of pig's bladder. Since then various graft materials like pig's bladder, Thiersch skin graft, Split-skin graft, Pedicle graft from ear canal skin, temporalis fascia graft, Vein graft, Sclera, Corneal graft, tympanic membrane homograft and perichondrium have been used for closure of the perforated tympanic membrane.

Various autografts have been used for repair of the tympanic membrane perforation like full thickness skin graft, Pedicled skin grafts (Frenckner 1955) ${ }^{5}$, split skin graft (Wullestein ${ }^{1} 1952$ and Zollner ${ }^{2}$ 1953), vein graft (Shea ${ }^{10}$ 1960), Fascia grafts (Heermann ${ }^{9}$ 1960) and Perichondrium (Jansen ${ }^{19} 1963$ and Goodhill ${ }^{22}$ 1967). Each of these grafts material has its advantages and disadvantages over each other. The healing of tympanic 
membrane perforation is preceded by ingrowths of connective tissue edges over which the epithelium migrates to close the perforation. Keeping this physiological principle in consideration it follows that connective tissue grafts, that is grafts of mesodermal origin like vein, perichondrium or fascia, prove superior to all other graft materials. Clinical investigations and animal experiments have shown that these connective tissues replace the missing fibrous element of the tympanic membrane and allow squamous epithelium and mucosal tissue to cover the medial and lateral surface.

Taking the above mentioned facts in consideration, this study was taken up to compare the results of the two connective tissue graft materials, viz temporalis fascia and the tragal perichondrium. The study includes the advantages and disadvantages of these graft materials vis-à-vis to each other.

\section{Aims And Objectives}

1. To do comparative study of underlay tympanoplasty with temporalis fascia and tragal perichondrium

2. We undertook this study to know the outcome of the surgery in respect with :

$>$ Graft uptake.

$>$ Hearing improvement .

$>$ Complications .

\section{Materials And Methods}

- Present study is a prospective trial which was carried out from January 2012 to August 2013 on the patients attending the ENT Outpatient Department M.G.M Medical college and Hospital Kamothe Navi Mumbai where tympanoplasty is performed using temporalis fascia in 20 patients and tragal perichondrium in 20 patients in the age group of 15-45 years (males and females both )

- Patients with the complaint of discharging ear and decreased hearing were screened.

- Patients, in whom tubotympanic type of chronic suppurative Otitis Media was found, were taken for this prospective study with randomization.

- The necessary permission and approval from ethics committee was taken.

- Informed written consents were obtained from the patients involved in the study according to the protocol approved by the Ethics Committee.

- This study comprises of patients who were subjected to tympanoplasty for the treatment of chronic suppurative otits media. Each patient was subjected to a detail examination of nose, paranasal sinuses and throat to rule out any focus of infection, which could influence the result of tympanoplasty. 20 Patients were subjected to tympanoplasty with temporalis fascia while the remaining 20 patients underwent with tragal perichondrium.

\section{Criteria for Selection}

\section{Inclusion Criteria}

$>$ Unilateral CSOM.

$>$ The ear should be dry minimum for 6 weeks with intact ossicular chain.

$>$ Patent Eustachian Tube.

$>$ Nonhealed traumatic perforation.

$>$ Patients of either sex with age group between $15-45$ years.

$>$ Patients willing to give written informed consent.

\section{Exclusion Criteria}

$>$ Unsafe CSOM

$>$ Safe CSOM with sensorineural hearing loss.

$>$ Patients < 15years > 45years.

$>$ Wet ear.

$>$ All ASOM cases.

$>$ Congenital hearing disorder.

$>$ Previous history of ear surgery.

\section{Method of Collection of Data}

- All the patients in the study were clinically evaluated by taking detailed history and clinical examination including Tuning fork test as per the proforma.

- Swab of ear discharge was sent for culture of organisms and antibiotic sensitivity.

- Antibiotics according to the sensitivity were given to dry up the ear discharge.

- Dry aural toilet was done to remove debris from ear canal. 
- Otomicroscopy was performed.

- Septic foci in the nose or in the throat were treated if present before ear surgery.

- Pure tone audiometry was done as per American speech and hearing association (ASHA).

- For all patients X-ray mastoid were taken ( Schuller view)

- Cases then were diagnosed and surgical plan of management was formulated.

- The patients routine Blood tests and urine tests were done for purpose of anaesthesia and to know the general condition of the patient .

- Anaesthesia fitness was done.

- Post operative at 3 months of follow up, patients subjective hearing was enquired and recorded.

- Post operative pure tone audiometry and ear microscopy was done in every case at the end of $3^{\text {rd }}$ month to record the hearing and graft uptake respectively.

\section{Operative Procedure}

Patients will be randomized and subjected to tympanoplasty by using tragal perichondrium or temporalis fascia

Positioning and Preparation: Patient is put in reversed Trendelenberg position with a head ring. Antiseptic dressing was done with betadine and draping was done.

Anaesthesia: Cases were operated under general or local anaesthesia after xylocaine sensitivity test. General anaesthesia was used in apprehensive patients.Local anaesthesia was achieved by using $2 \%$ xylocaine with 1:200,000 adrenaline in the subcutaneous tissue of post auricular region and four quadrant of external auditory canal.

\section{Follow Up:}

Patients will be followed up after 1 st week, $2^{\text {nd }}$ week, one month, and third month after surgery. At follow up patients will be evaluated by otoscopic examination to determine the condition of the graft, pure tone audiometry is done to calculate air bone gap closure will be assessed.

Data Analysis - Observations were tabulated on a spread sheet by using Microsoft excel. Statistical analysis of the patients was carried out with Student' $\mathrm{t}$ ' test and " $\mathrm{Z}$ " test. A 'P value' $<0.05$ was considered statistically significant.

\section{Table-1: Sex Distribution}

\section{Results:}

The above table indicates that there were $18(45 \%)$ males and $22(55 \%)$ females. The male to female ratio is 1:1.22.

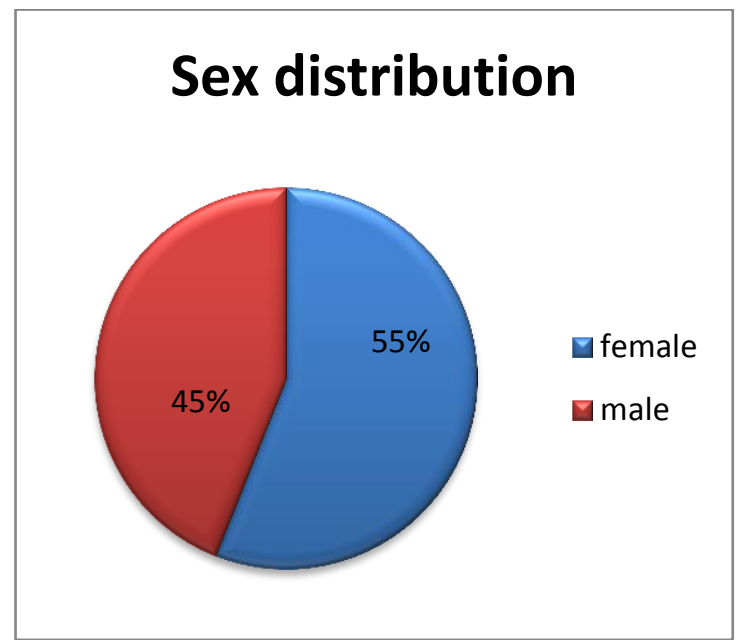


Table-2: Shows Age wise Distribution

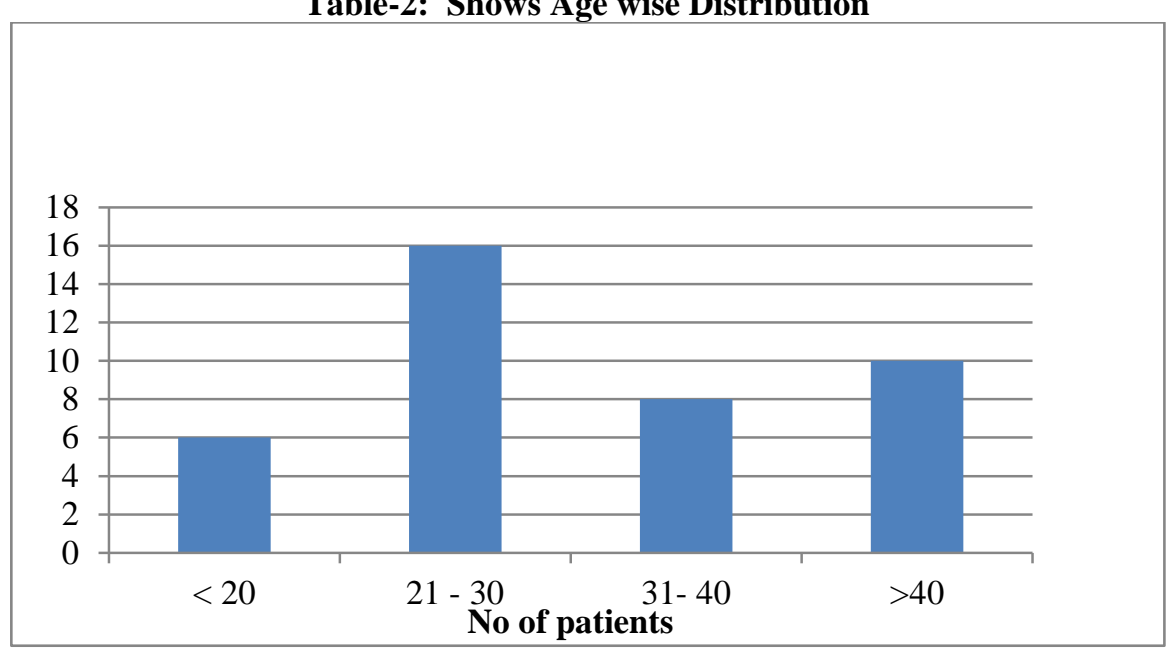

Table-3: Preoperative Hearing Levels.

\begin{tabular}{|c|c|c|c|c|}
\hline \multirow{2}{*}{$\begin{array}{l}\text { Preoperative } \\
\text { Air- Bone Gap }\end{array}$} & \multicolumn{3}{|c|}{ No. of Patients } & \multirow[b]{2}{*}{ Percentage } \\
\hline & $\begin{array}{l}\text { Temporalis } \\
\text { Fascia }\end{array}$ & Tragal Perichondrium & Total & \\
\hline$<20$ & 10 & 09 & 19 & $47.5 \%$ \\
\hline $21-40$ & 10 & 11 & 21 & $52.5 \%$ \\
\hline$>40$ & 0 & 0 & 0 & $0 \%$ \\
\hline
\end{tabular}

Majority of the patients shows mild to moderate hearing loss.

$47.5 \%$ of them had air-bone gap up to $20 \mathrm{~dB}$.

$52.5 \%$ of them had air-bone gap 21-40 dB.

None of them had air-bone gap above $40 \mathrm{~dB}$.

Table-4: Postoperative Hearing Levels.

\begin{tabular}{|l|l|l|l|l|}
\hline \multirow{2}{*}{$\begin{array}{l}\text { Postoperative } \\
\text { Air- Bone Gap }\end{array}$} & No. of Patients & \multirow{2}{*}{ Percentage } \\
\cline { 2 - 5 } & $\begin{array}{l}\text { Temporalis } \\
\text { Fascia }\end{array}$ & Tragal Perichondrium & Total & \\
\hline$<20$ & 16 & 15 & 31 & $77.5 \%$ \\
\hline $21-40$ & 4 & 5 & 9 & $22.5 \%$ \\
\hline$>40$ & 0 & 0 & 0 & $0 \%$ \\
\hline
\end{tabular}

In the postoperative hearing analysis,

$77.5 \%$ of the patients showed air- bone gap upto $20 \mathrm{~dB}$

$22.5 \%$ of the patients showed air- bone gap in the range of $21-40 \mathrm{~dB}$.

$80 \%$ of the patients operated with temporalis fascia showed air bone gap upto $20 \mathrm{~dB}$.

$75 \%$ of the patients operated with tragal perichondrium showed air-bone gap upto $20 \mathrm{~dB}$.

Table-5: Postoperative Hearing Levels with Respect to Sex.

\begin{tabular}{|l|l|l|l|l|}
\hline \multirow{2}{*}{$\begin{array}{l}\text { Postoperative } \\
\text { Air- Bone Gap }\end{array}$} & No. of Patients & Female & Total & \multirow{2}{*}{ Percentage } \\
\cline { 2 - 5 } & Male & 17 & 32 & $80 \%$ \\
\hline$<20$ & 15 & 5 & 8 & $20 \%$ \\
\hline $21-40$ & 3 & 0 & 0 & $0 \%$ \\
\hline$>40$ & 0 & & \\
\hline
\end{tabular}

In the postoperative hearing analysis.

$75 \%$ male patients showed air bone gap upto $20 \mathrm{~dB}$.

$85 \%$ female patients showed air bone gap upto $20 \mathrm{~dB}$. 
Table 6: Post Operative Hearing Improvement Level

\begin{tabular}{|l|l|l|l|l|}
\hline \multirow{2}{*}{$\begin{array}{l}\text { Mean change in } \\
\text { hearing levels in dB }\end{array}$} & No of patients & Percentage \\
\cline { 2 - 5 } $\begin{array}{l}\text { No change or } \\
\text { worsen }\end{array}$ & 4 & 5 & 9 & $22.5 \%$ \\
\hline $1-15$ & 16 & 15 & 31 & $77.5 \%$ \\
\hline $16-30$ & 4 & 5 & 9 & $22.5 \%$ \\
\hline$>30$ & 0 & 0 & 0 & $0 \%$ \\
\hline
\end{tabular}

Hearing at 3 months, 31 out of 40 patients showed improvement in hearing (77.5\%). Out of these patients, 16 out of 20 patients were operated using temporalis fascia showed improvement in hearing i.e. $(80 \%)$ and 15 out of 20 patients were operated using tragal perichondrium showed improvement in hearing i.e. (75\%). There is not much statistical significant difference in hearing improvement, using temporalis fascia or perichondrium for tympanoplasty.

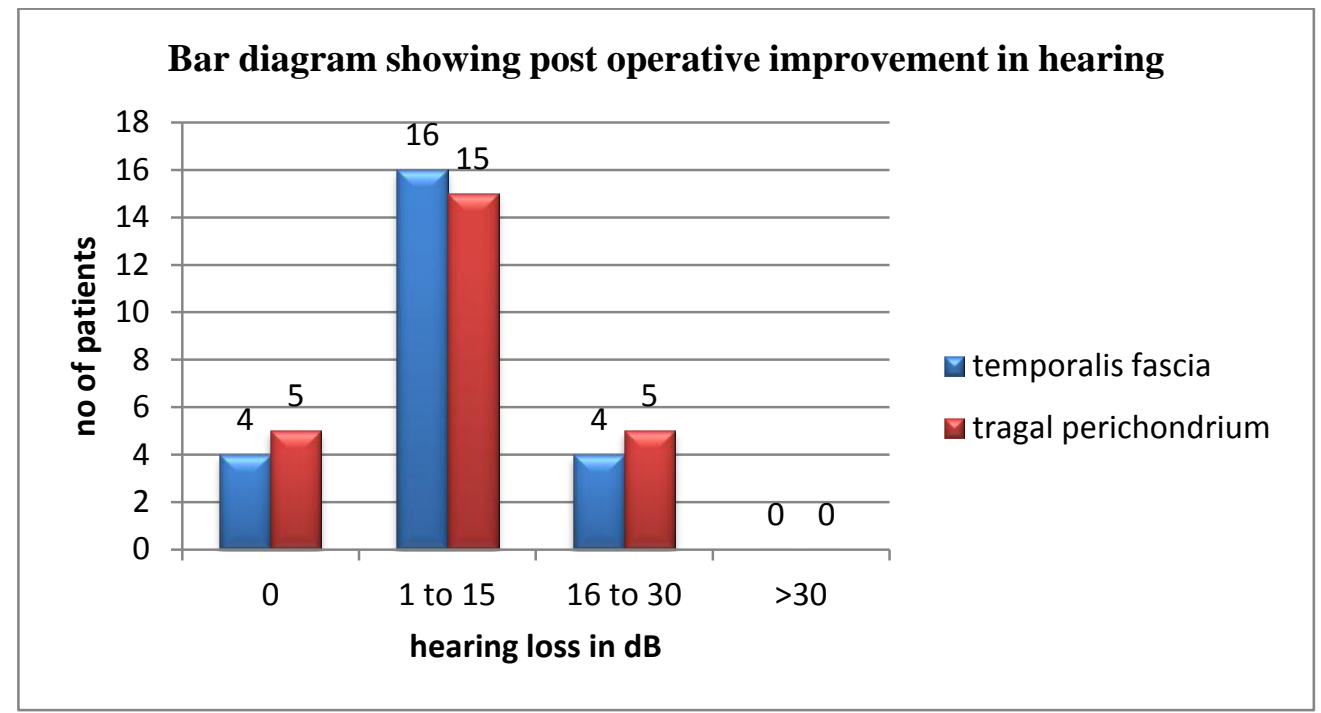

Table 7: Mean Hearing Level in Tympanoplasty using Temporalis Fascia and Tragal Perichondrium

\begin{tabular}{|l|l|l|l|}
\hline \multirow{2}{*}{ Type of graft } & Mean levels of hearing & \multicolumn{2}{|c|}{} \\
\cline { 2 - 4 } & Preoperative hearing levels & Post operative hearing levels & $\begin{array}{l}\text { Post operative change in } \\
\text { hearing }\end{array}$ \\
\hline Temporalis fascia & $399 / 20=19.99$ & $209 / 20=10.45$ & $190 / 20=09.5$ \\
\hline $\begin{array}{l}\text { Tragal } \\
\text { perichondrium }\end{array}$ & $452 / 20=22.6$ & $272 / 20=13.6$ & $180 / 20=9$ \\
\hline Total & $851 / 40=21.27$ & $481 / 40=12.02$ & $370 / 40=9.25$ \\
\hline
\end{tabular}

- Mean improvement in hearing temporalis fascia is $09.5 \mathrm{~dB}$

- Mean improvement in hearing using tragal perichondrium is $09.0 \mathrm{~dB}$.

$\mathrm{P}>0.05$, we found that there was no statistically difference in mean improvement in hearing using either temporalis fascia or tragal perichondrium. 


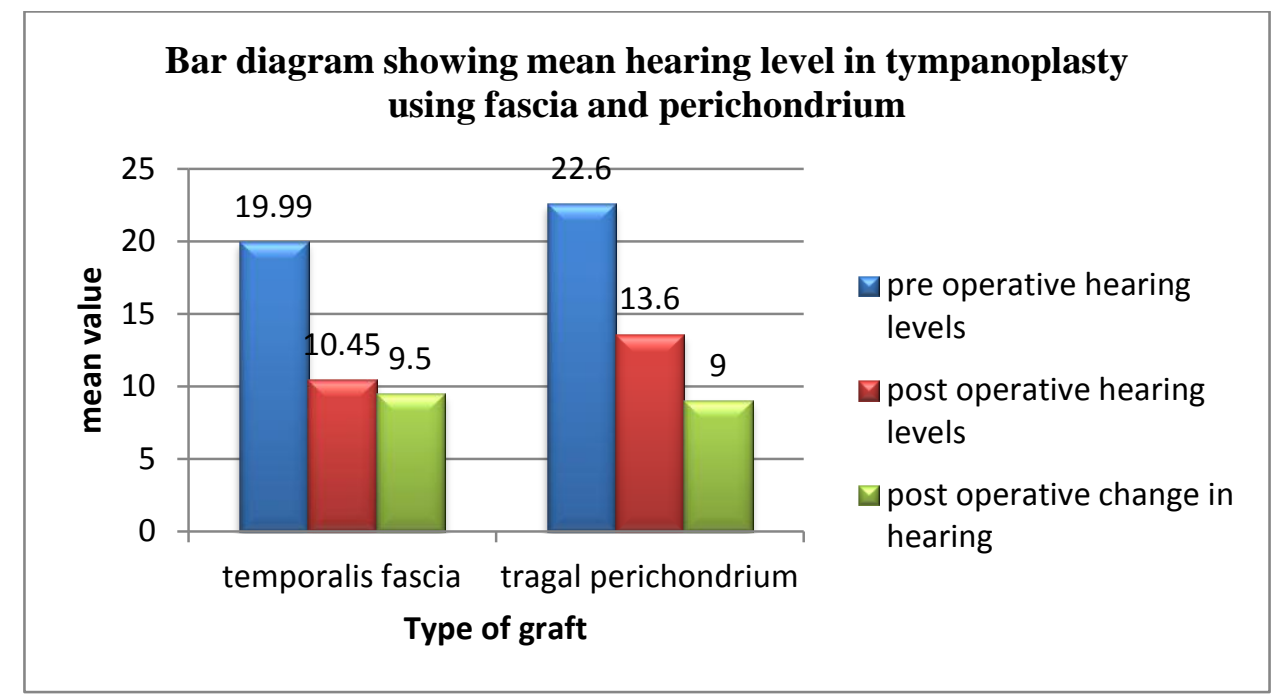

Table no 8: Graft Uptake Rate

\begin{tabular}{|l|l|l|}
\hline Type of graft & Graft uptake & Percentage \\
\hline Temporalis fascia & $16 / 20$ & $80 \%$ \\
\hline Tragal perichondrium & $15 / 20$ & $75 \%$ \\
\hline Overall & $31 / 40$ & $77.5 \%$ \\
\hline
\end{tabular}

The above table indicates that $16(80 \%)$ out of 20 ears operated using temporalis fascia graft healed completely at the end of 3 months with well taken graft.15 (75\%) out of 20 ears operated using tragal perichondrium were dry with graft in place at the end of 3 months . No statistical significant association was found in graft uptake with respect to type of graft $(\mathrm{P}>0.05)$.

$\mathrm{Z}=0.36, \mathrm{p}>0.05$

Most of the smaller perforations here were taken for tympanoplasty when they failed to respond to medical treatment and weekly trichloro - acetic acid cautery or when patient cannot come for repeated sittings.

\section{Factors Affecting Graft Take Rate}

Age and sex of the patients were also compared with graft take rate:

Table 9: Graft Uptake Rate with Respect to Age of the Patients $(n=40)$.

\begin{tabular}{|l|l|l|}
\hline Age in years & No of patients & Percentage \% \\
\hline$\leq 20$ & $4 / 6$ & 66.66 \\
\hline $21-30$ & $14 / 16$ & 87.5 \\
\hline $31-40$ & $6 / 8$ & 75 \\
\hline$>40$ & $7 / 10$ & 70 \\
\hline
\end{tabular}

From the above table it is seen that maximum graft uptake rate observed in the age group 21-30 years $(87.5 \%)$.

Table 10: Graft uptake Rate With Respect to Sex $(n=40)$.

\begin{tabular}{|l|l|l|}
\hline Sex & Graft uptake & Percentage \% \\
\hline Male & $14 / 18$ & $77.77 \%$ \\
\hline Female & $17 / 22$ & $77.27 \%$ \\
\hline
\end{tabular}

The above table shows that graft uptake rate was $77.77 \%$ ( 14 out of 18 ears) in males and $77.27 \%$ ( 17 out of 22 ears) in female.

$\mathrm{Z}=0.75, \mathrm{P}>0.005$

There is no statistical significant difference seen in graft uptake rate in sex. 


\section{Discussion}

This is the prospective study of 40 tympanoplasties on patients between the age of 15 to 45 years, who were admitted in the Department Of E.N.T and Head and Neck Surgery at M G M Medical College, Kamothe, Navi Mumbai , between January 2012 to August 2013. This entire study group of patient suffered from Chronic Suppurative Otits Media. Patients in this study were from all socioeconomic groups, including patients referred from other practitioners also.

Conservative measures were first tried in all cases, particularly for small to moderate sized perforations. These included systemic antibiotics, trichloro-acetic acid cautery, repeated aural toilet in ears with active infections. Cases of ear diseases with suspected central septic focus were operated with tonsillectomy, adenoidectomy, septoplasty, etc. as needed before ear surgery. 20 patients were subjected to tympanoplasty with temporalis fascia remaining 20 with tragal perichondrium. Follow up of postoperative cases was for 3 months.

\section{Duration of Pre operative Dry Ear}

Palva et al $(1987)^{35}$ in their study of 165 cases of myringoplasties, which was carried out only when the ear was dry for atleast 3 months success rate was $96 \%$.

Gibb AG, Chang SK $(1982)^{30}$ in their study of 206 cases of underlay myringoplasty found the uptake rate of 91.4\% for dry ear and $80.9 \%$ for wet ear.

Gersdoff $\mathrm{M}$ et al. (1995) ${ }^{51}$ long term result of myringoplasty in adult and children and found the state of middle ear at the time of operation influences surgical outcome; wet ear have higher rate of reperforation.

Brown C et al. (2002) ${ }^{55}$ in their study of 165 cases of myringoplasty found success rate $75 \%$ if perforation is dry $64 \%$ if perforation is wet.

In our study of 40 cases of tympanoplasty all cases had dry ear preoperatively atleast for 6 weeks hence overall graft uptake rate was $77.5 \%$, which correlates well with the quoted literature.

\section{Technical Aspects}

Tympanoplasty is technically more difficult in patients having a narrow canal, undergoing revision surgery, by transcanal approach and in anterior perforations.

Post-auricular approach is commonly used in our institution;

The contour of tragus was found to be satisfactory in postoperative period without any cosmetic deformity.

\section{Graft Uptake Rate}

The graft take rate after 3 months was $77.5 \%$. Similar report was given by Palva T et al $(1995)^{52}$ with graft take rate were $97 \%$.

In our study, graft uptake rate for temporalis fascia was $80 \%$ as compared to tragal perichondrium was 75\%. Graft take-rate was slightly better for temporalis fascia than for tragal perichondrium (not significant $\mathrm{p}>>0.005$ ). This marginal difference however, is not significant. Various studies showed the grafts uptake was in the ratio of 80 to $90 \%$, for either temporalis fascia or tragal perichondrium.

These reports compare well with similar study conducted by Jyoti P Dabholkar $(2007)^{56}$ whose postoperative graft uptake rate with temporalis fascia was $84 \%$ and tragal perichondrium showed $80 \%$.

Jain CM $(1968)^{24}$ who reports $83.33 \%$ success rate with temporalis fascia, Ahad SA $(1986)^{31}$, with $83.30 \%$ success with homologous temporalis fascia, Blanshard JD $(1990)^{41}, 78 \%$ take-rate with temporalis fascia in pediatric tympanoplasty. P.K Parida, S.K Nochikattil $(2012)^{57}$ in their study found $80 \%$ uptake rate with temporalis fascia. perichondrium.

Quraishi et al ${ }^{50}$ reported success rate of $94 \%$ in 32 cases of primary myringoplasty with tragal

Most of graft failures seen in the follow-up period were due to infection probably transmitted either along Eustachian tube or along external auditory canal.

\section{Hearing Result}

$77.5 \%$ of cases showed improvement in hearing, while $22.5 \%$ of them showed no improvement, at 3 month follow-up period. About $80 \%$ cases operated with temporalis fascia showed hearing improvement, while similar percentage (75\%) of cases who were operated using tragal perichondrium showed improvement in hearing (statistically not significant $\mathrm{p}>>0.05$ ) as shown in the Table-6.

Mean improvement in hearing using temporalis fascia was $09.50 \mathrm{~dB}$ and that with tragal perichondrium it is $09.0 \mathrm{~dB}$ (statistically not significant $\mathrm{p}>>0.05$ ) as shown in Table -7 . These results compare well with Strauss et al (1975) who found that improvement in air bone gap was $15 \mathrm{~dB}$. These result also compare well with Ophir D $(1987)^{37}$, Terry RM $(1988)^{38}$, result with fat myringoplasty.

Hartwein $(1992)^{46}$ claims reduction of air bone gap of around $15 \mathrm{~dB}$ with tragal perichondrium graft. 
Jyoti P. Dabhalkar $(2007)^{56}$ reported hearing result in total 50 patients, temporalis fascia group improved in $76 \%$ while tragal perichondrium group achieved $75 \%$ hearing gain.

This study also compares well with Sunita Chhapola, Inita Matta $(2011)^{58}$ whose postoperative hearing assessed after 6 months of surgery, with temporalis fascia graft showed air bone gap of less than 10dB in $82 \%$ of patients and more than $10 \mathrm{~dB}$ in $18 \%$ patients, air bone gap closure with tragal perichondrium was less than $10 \mathrm{~dB}$ in $78 \%$ patients and more than $10 \mathrm{~dB}$ in $22 \%$ of patients.

The patient population attending our hospital was also from low socioeconomic status, many had poor personal hygiene and poor nutritional status. These were probably some of the factors which contribute to graft rejection.

\section{Factors Affecting Graft Take-rate}

Size of perforation operated in our study were small / moderate central perforation. Uptake rate was nearly similar for all the sites and sizes of perforations, maximum for perforation in posterior quadrant of the drum, followed by perforation in anterior quadrant of the drum and also perforation in both the quadrants of the drum have healed well. Finally, then take-rate is not influenced by site and size of perforation.

Similar opinion is expressed by Blanshard JD (1990) ${ }^{41}$ who opines that age at operation, size of perforation and prior adenoidectomy had no significant influence on the success rate or audiological outcomes. Factor such as duration of illness, age and sex of patients, did not significantly affect graft uptake rate in our study. Vartiainen E (1993) ${ }^{49}$ also states that the preoperative factor like dryness or discharging ear, site of perforation of technique (onlay/underlay) do not affect the take rate.

Berger $\mathrm{G}$, et al $(1997)^{54}$, stated that results of myringoplasty were independent of patient's age ,sex, location and size of perforation .

\section{Conclusions}

- Tympanoplasty is the most effective method for control of the tubotympanic type of CSOM disease and hearing improvement.

- Both temporalis fascia and tragal perichondrium are excellent graft materials for closure of perforation of tympanic membrane and hearing improvement.

- Graft uptake rate is good for both with slightly better take rates for temporalis fascia, than tragal perichondrium.

- Hearing improvement does not depend on type of graft (No statistically significant difference - p >>0.5).

- In our study, uptake rate of graft was neither influenced by the site or size of the perforation.

- Improvement in hearing is not significantly influenced by duration of disease, age or sex of patients.

\section{Summary}

- 40 tympanoplasties were performed on indoor basis.

- Age range from 15-45 years with mean age of patients 29.12 years.

- $18(45 \%)$ males and $22(55 \%)$ females with male to female ratio 1:1.22.

- Majority of the patients preoperatively showed mild to moderate hearing loss. $47.5 \%$ patients showed up to $20 \mathrm{~dB}$ air bone gap range, $52.5 \%$ patients showed $21-40 \mathrm{~dB}$ air-bone gap and none of the patients showed above 40dB.

- Surgeries were performed by post-aural approach.

- In all surgeries grafts were placed as underlay technique.

- $20(50 \%)$ patients were operated using temporalis fascia and $20(50 \%)$ patients using tragal perichondrium.

- Graft take rate was overall $77.5 \%$.

- All the patients selected for tympanoplasty had dry ear for atleast 6 weeks which might explain good graft take rate of $77.5 \%$.

- Graft uptake rate was $80 \%$ with temporalis fascia and $75 \%$ with tragal perichondrium.

- In postoperative hearing analysis, $80 \%$ patients showed air-bone gap up to $20 \mathrm{~dB}$.

- Overall mean improvement in hearing was $09.25 \mathrm{~dB}$.

- Mean improvement in hearing for temporalis fascia was $09.5 \mathrm{~dB}$ and for tragal perichondrium was $09.0 \mathrm{~dB}$.

- Uptake rate of graft was not influenced by the size/ site of perforation.

- Improvement in hearing was also not significantly influenced by the type of graft used. 


\section{References}

[1]. Wullestein H. Method for split-skin covering of perforation of the drum by tympanoplasty operations in cases of chronic otitis. Arch Ohr Nas- u.Kehlk -Helik 1952; 161:422.

[2]. Zollner F. Tympanoplasties intented to replace large drum defects combined with defects of ossicles. Panel on myringoplasty. Second workshop on reconstructive Middle Ear Surgery. Arch Otolaryng 1953; 78:301.

[3]. Zollner F. Abandoned split skin graft because of its low resistance, preferring full thickness retro- auricular skin grafts. Proc 5 Int Congr Otolaryng 1953; 119.

[4]. Mc Laughlin, C.R. Composite ear grafts and their blood supply. Brit J Plast Surg 1954 Oct; 7(3):274-8

[5]. Frenckner P. Pedicle graft from ear canal skin for myringoplasty. Acta Otolaryng 1955; $45: 19$.

[6]. Wright WK. Repair of chronic central perforation membrane: by repeated acid cautery by skin grafting Laryngol. (St. Louis) 1956; 66: 1464 .

[7]. Wullestein H. Reported series tympanoplasties of 1000 cases. Arch Ohr-u.Kehlk-Heilk. 1957; $171: 84$.

[8]. GuilfordFR, Wright WK and Draper WL. Tympanic skin grafting and reconstruction of the middle ear sound conducting mechanism. Arch. Otolaryng. 1959; 69: 70.

[9]. Heerman H. Thorough description of a method of fascial grafting. HNO. 1960; 9: 136

[10]. Shea JJ. Vein graft closure of ear drums perforations. J. Laryng. 1960; 74: 358.

[11]. Link R. Corium graft a skin graft without epithelium takes much more easily. Arch Ohr-Nas-u.Kehlk-Heilk. 1960; 176 : 462

[12]. Agazzi C. Long term of series of 292 tympanoplasties. Laryng Rhinol. 1960; 39: 351.

[13]. Stoors LA. Myringoplasty with the use of fascia grafts. Arch Otolaryng.1961; 74: 45.

[14]. Schlosser WD Pratt LL. An evaluation of various tympanoplasty techniques. Arch Otolaryngol. 1961 Oct; 74: $429-34$.

[15]. Soofy FA and Hambley WM. Myringoplasty techniques. Arch Otolaryng. 1961; 71: 429.

[16]. Booth TE. Restoration of hearing by tympanoplasty.Laryngoscope (St.Louis). 1961; 74:45.

[17]. Proctor B. Tympanoplasty Arch Otolaryng.1962; 76: 377.

[18]. Austin DF. Vein graft tympanoplasty: two year report. Trans Amer Acad Ophthal Otolaryng. 1963; 67: 198-208.

[19]. Jansen C. Use of free tissue transplants of autogenous nasal septal perichondrium. Laryngoscope.1963; 73:78: 394.

[20]. Zollner F. Threapy of Eustachian tube patency in tympanoplasty. Arch Otolaryn.1963; $78: 394$.

[21]. Farrior JB. Total tympanoplasty type -V. Eustachian tube patency in tympanoplasty. Arch Otolaryn. 1965; 81:398-409.

[22]. Goodhill V. Tragal perichondrium and cartilage for myringoplasty. Arch Otolaryn. 1967; 71:480-491.

[23]. Sheely JL, Glassocock ME. Tympanic membrane grafting with temporalis fascia. Arch Otolaryn. 1967; 86:391-402.

[24]. Jain CM. Technique of myringoplasty using a fascial graft. Indian J Otolaryngol. 1968; 20(4): 173.

[25]. Sengupta RP and Kacker SK. Study of Eustachian tube with particular reference to long term follow up in myringoplasty.Ind J Otol.1974; 26:132-137.

[26]. Kacker SK. Suggestions for improving result in myringoplasty. Ind J Otol.1976; 28:73-75.

[27]. Plester D.Steinbach E. Histological fate of tympanic membrane and ossicle homografts. Otololaryngologic Clinics of North America.1977; 10(3):478-99.

[28]. Packer P. What is best in myringoplasty; underlay or overlay dura or fascia. J Laryngology and otology.1982; 96:25-41

[29]. Gerrit J Hordijk. Tympanic membrane grafting with fascia, pericardium and vein. J Laryngology and otology.1982; 96:43-47.

[30]. Gibb AG, Chang. Myringoplasty (A review of 365 operations). Journals of Laryngology and Otology 1982 Oct; 96(10):915-30.

[31]. Ahad SA. Myringoplasty using homologous temporalis fascia. Ind J Otol. 1986; 33:28-29.

[32]. Isiah V. Geriatric myringoplasty. Ind J Otolar. Suppl of Report of $38^{\text {th }}$ Annual Conference of A.O.I. 1986.

[33]. Kumaresean M. Vascular myringoplasty. Ind J Otolar. 1986; 38(4) :127

[34]. Gordon H Epstein. Biologic and nonbiologic materials in otologic surgery. Otolaryngologic Clin of N Am. 1986; 20(1): 45-53.

[35]. Palva T. Surgical treatment of chronic ear disease 1. Myringoplasty and tympanoplasty. Acta Otolaryngol. (Stockh) 1987; 104(3-4): 279-284.

[36]. Tos M. Autologous tissue seal in myringoplasty. Laryngoscope. 1987; $97(3$ pt 1): 370-371.

[37]. Ophir D. Myringoplasty in paediatric population. Arch Otolaryngol Head and Neck Surg. 1987; 113(2): 1288-1290.

[38]. Terry RM. Fat graft myringoplasty: Aprospective trial. Clin Otolaryngol. 1988; 13(3): 227-229.

[39]. Gross CW. Adipose plug myringoplasty an alternative to formal myringoplasty technique in children. Otolaryngol Head \& Neck Surg. 1989; 101(6): 427-434.

[40]. Marcos V Goycoolea. Grafting of tympanic membrane. Atlas of Otologic Surgery, Edited by Goycoolea MV, WB Saunders Company, 1989; 220.

[41]. Blandshard JD. A long term view of myringoplasty in children. J Laryngol. Otol. 1990; 104(10): $758-762$.

[42]. Wormald PJ. Anatomy of the temporalis fascia. J Laryngol. Otol. 1991; 105(7): 522-524.

[43]. Kaddor HS. Myringoplasty under local anaesthesia: Day care surgery. Clin Otolaryngol. 1992; 17(6): 567-568.

[44]. Pagnini P. Sandwich - graft myringoplasty: The author's personal technique and result. Acta Otorhinolaryngol Ital. $1992 ; 153-163$.

[45]. Sitnikov VP. A method of myringoplasty used in patient; with extensive defects of tympanic membrane. Vestn Otorhinolaryngol. 1992; 3: 31-33.

[46]. Hartwein J. "Crown-cork tympanoplasty" a method completes reconstruction of tympanic membrane. Laryngor-Hinoootogies. 1992; 71(2): 102-105.

[47]. Verbist M. High frequency thresholds prior to and following middle ear surgery. Acta Otorhinolaryngol Belg. 1993; 47(1): 17-21.

[48]. Ajula SO, Myatt HM, Alusi G. Peri-umbilicus superficial fascia graft myringoplasty - a simple alternative. Clin Otolaryngol Allied Sci. 1993; 18(5): 433-435.

[49]. Vartiainer E. Findings in revision myringoplasty. Ear Nose and Throat J. 1993; 72(3): 201-204.

[50]. Quareshi MS, Jones NS. Day care myringoplasty using tragal perichondrium. Clin Otolaryngol Allied Sci. $1995 ; 20(1): 12$.

[51]. Gersdoff M,Grain P, Decat M,Jugantegui M.Myringoplasty :Long term result in adult and children.American Journal of otology1995 Jul ; 16(4):532-5

[52]. Palva T, Ramsay H. Myringoplasty and tympanoplasty- results related to training and experience. Clin Otolaryngology Allied Science. 1995; 20: 329-335.

[53]. Mitchell RB, Pereira KD, Lazar RH. Fat graft myringoplasty in children - a safe and successful day stay procedure. J Laryngol Otol. 1997; 111(2): 106-108.

[54]. Berger G, Ophir D, Berco E, Sade J. Revision myringoplasty. J Laryngol. Otol. 1997; 111(6): 517-520.

[55]. Brown C,Yi Q,Mc Carty DJ. The success rate following myringoplasty at the Royal Victorian Eye and Ear Hospital. Austarlian Journal of Otolaryngology:2002 Aprl. 
[56]. Jyoti P Dabholkar. Comparative study of underlay tympanoplasty with temporalis fascia and tragal perichondrium. Ind.Otolaryngol Head Neck Surg. 2007; 116-119.

[57]. P.K. Parida, S.K Nochikatil. A Comparative Study of Temporalis Fascia Graft and Vein Graft in Myringoplasty. Ind.Otolaryngol Head Neck Surg. 2011: 0543-4.

[58]. A. Sengupta, B.Basak. A study on outcome of underlay,overlay and combined technique of myringoplasty. Ind.Otolaryngol Head Neck Surg. 2011; 64(1): 63-66. 